\title{
RUBUS AMBROSIUS (RUBUS SUBSECT. RUBUS, Rosaceae), a NeW BRAMBle SPECIES fRom the EASTERN PART OF CENTRAL EUROPE
}

\author{
Bohumil Trávníček ${ }^{1)}$, Krzysztof Oklejewicz $^{2)}$ \& Jerzy Zieliński ${ }^{3)}$ \\ 1) Department of Botany, Palacký University Olomouc, Faculty of Science, Svobody 26, CZ-771 46 Olomouc, \\ Czech Republic; e-mail travnicek@prfholnt.upol.cz \\ 2) University of Rzeszów, Biotaxonomy Department, ul. Cegielniana 12, PL-35-959 Rzeszów, Poland; e-mail \\ koklej@univ.rzeszow.pl \\ 3) Polish Academy of Science, Institute of Dendrology, Parkowa 5, PL-62-035 Kórnik, Poland; e-mail \\ jeziel@rose.man.poznan.plor jeziel@poczta.onet.pl
}

\begin{abstract}
Rubus ambrosius TRÁVNíČEK et OKLEJEWICZ, a widely distributed species from the eastern part of Central Europe (Czech Republic, Slovakia and Poland), is described. R. ambrosius differs from similar species $R$. sulcatus VEST by more deeply furrowed stems, longer prickles on first-year tems, longer petioles, more prickly petioles, densely hairy leaves beneath and by blunter leaf margin serration with incisions only (2-)1.5-2.5 mm deep. The newly described species is illustrated both by photographs (including the holotype) and a line drawing. A list of localities and a distribution map are presented.
\end{abstract}

Keywords: Apomictic species, Czech Republic, Distribution, Poland, Rubus subg. Rubus, Slovakia, Taxonomy

\section{INTRODUCTION}

Within the European flora, Rubus L. subgen. Rubus is one of the most taxonomically complicated groups. In Central Europe, the representatives of the group form a complex comprising few sexual species and innumerable polyploid apomicts (WEBER 1995). New morphotypes evolve through casual hybridization with subsequent splitting and can stabilize by renewed apomixis (see WEBER 1995, MATZKE-HAJEK 1997, etc.). Taxonomic study of subgenus Rubus has been burdened with fatal methodological errors in the past (for details see HOLUB 1992, WEBER 1995, 1996, 1999) connected with an inappropriate species concept. However, in the last 30 years, a new, modern species concept has been developed and used consistently in the subgenus Rubus (HOLUB 1992, WEBER 1995, 1996, 1999). Only genetically uniform morphotypes with sufficiently large distribution areas - diameter more than (20-) $50 \mathrm{~km}$ - have been classified as species in modern batology.

Rubus subgen. Rubus subsect. Rubus (= section Suberecti LiNDL.) represents a rather uniform group of European apomictic brambles. It contains several well-known and widespread species, that are relatively common in Central Europe, including Rubus sulcatus VEST (see WEBER 1995: 351). R. sulcatus is a relatively easily distinguishable species differing from other representatives of Rubus subsect. Rubus in having robust, highly arcuate, first-year stems with strong, 5-9(-10) $\mathrm{mm}$ long prickles, longer $(5-10 \mathrm{~mm})$ petiolules of basal 
leaflets, terminal leaflets with an abrupt, conspicuously elongated (usually 19-28 mm) apex and large flowers with stamens longer than the styles.

In the course of our field exploration of brambles in various regions of the eastern part of Central Europe (namely in Slovakia, Poland and the Czech Republic) in 1992-2004 we repeatedly observed and collected an interesting Rubus taxon close in appearance to Rubus sulcatus, but differing from it in several important features. Further study indicated that the taxon represents a new, hitherto neglected and therefore undescribed Rubus species. This species has been preliminarily named as $R$. ambrosius (nom. prov.), and this name was used in several papers (see HoluB \& TRÁVNÍČEK 1998: 601, HOLUB 1999: 7, 16, HOLUB \& PROCHÁZKA 2000: 205, PROCHÁZKA 2001: 34, TRÁVNíČEK \& HAVLÍČEK 2002: 331, 344). The species is described and its provisional name is validated below.

\section{MATERIAL AND METHODS}

The newly distinguished species Rubus ambrosius was described mainly according to the plants gathered by the authors when studying brambles in Central Europe (Poland, Czech and Slovak Republics) in 1991-2004. The old collections in institutional herbaria, containing often improperly preserved or mixed specimens, have not been used. For the study of $R$. sulcatus the collections of the first author, housed in herbarium OL, were used. Morphometric values given in the morphological description of $R$. ambrosius and in the table of comparative characters (Table 1) were measured on 30 herbarium specimens of $R$. ambrosius and on the same number of specimens of $R$. sulcatus. Values given in brackets represent 10 per cent of variation of the respective character.

\section{DESCRIPTION OF A NEW SPECIES}

Rubus ambrosius TrÁVNíČEK et OKLEJEWICZ, sp. nov. (Figs. 1-5)

Diagnosis: Rubo sulcato VEST quoad habitum similis, sed turio angulatus cum faciebus semper distincte profunde sulcatis, glandulis sessilibus conspicue obsitus, in numero (40-)70-180(-230) pro $1 \mathrm{~cm}$ lateris. Aculei turionis sat graciles, paulo reclinati vel fere patentes, recti usque paulo curvati (6-)7-11(-12) mm longi, in numero (2-)3-6(-7) ad $5 \mathrm{~cm}$ longitudinis. Folia turionis subtus pilis brevis subpatentibus satis dense instructa, plerumque ad tactum perceptilibus usque molliter pilosa. Petiolus $(7-) 8-10(-12) \mathrm{cm}$ longus, foliolis infimis plerumque longior, cum aculeis in numero (5-)9-16(-20) munitus. Serratura laminulae sat subtilior, e dentibus saepe latioribus quam longis, incisurae tantum (1-)1.5-2.5 $\mathrm{mm}$ profundae. Folia in parte superiori inflorescentiae serotini (paniculati) trivialiter canescente-viridia, pilis subpatentibus dense obsita. Flores vulgo tantum mediocres, $(1.5-) 2.0-2.7(-3.0) \mathrm{cm}$ in diametro. Sepala externe cano-viridia, subadpresse denseque pilosa, cum marginibus albo-tomentosis. Fructus parvus usque mediocris, plerumque globosus.

Holotype: Czech Republic; NE Moravia (Silesia), Šilheřovice village near Ostrava town, bushes along the road towards Markvartovice village. Coll. B. TRÁVNíčEK 5.VIII.1998 OL (R70/98) (Fig. 1). 


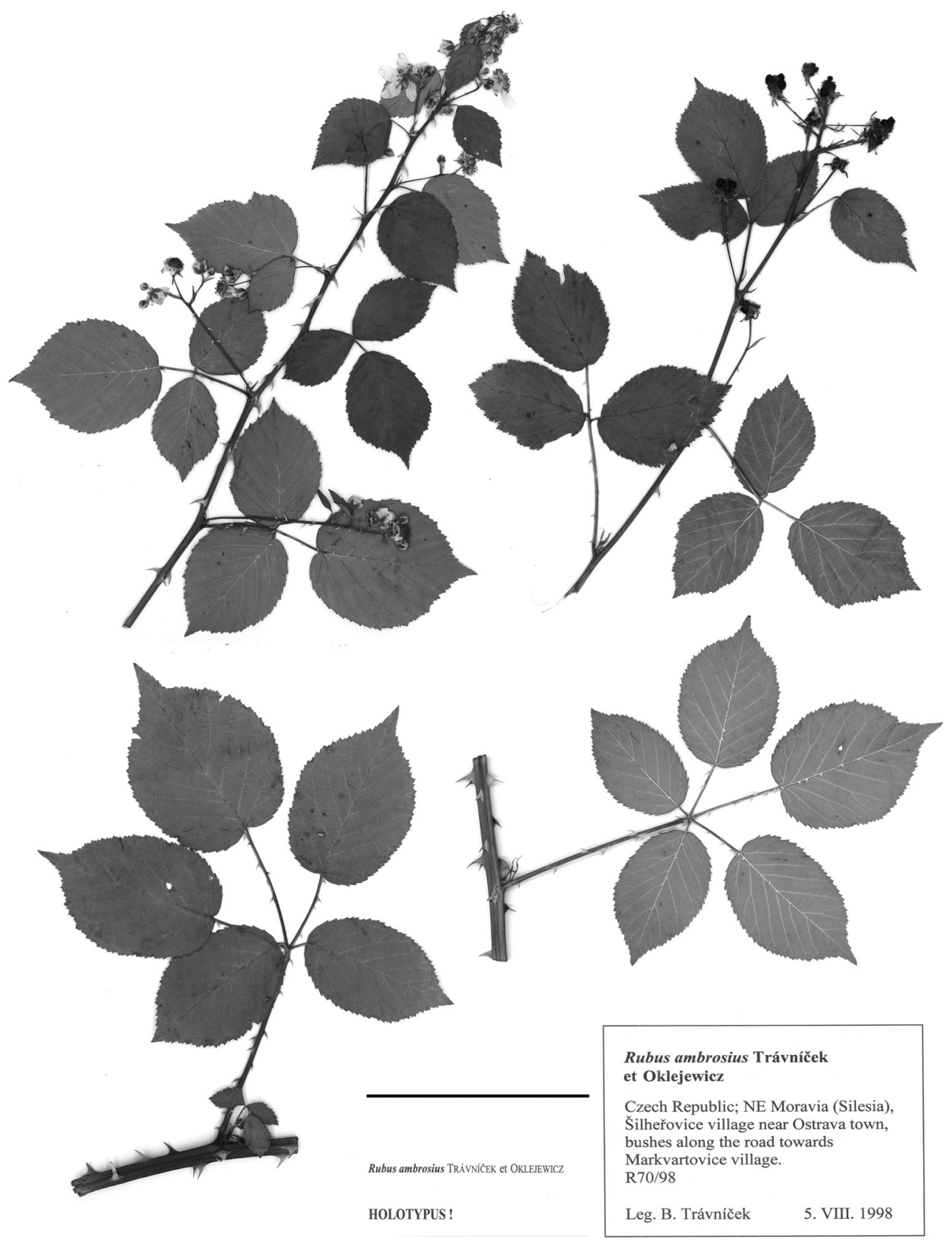

Fig. 1. Rubus ambrosius, holotype; bar $=10 \mathrm{~cm}$. 


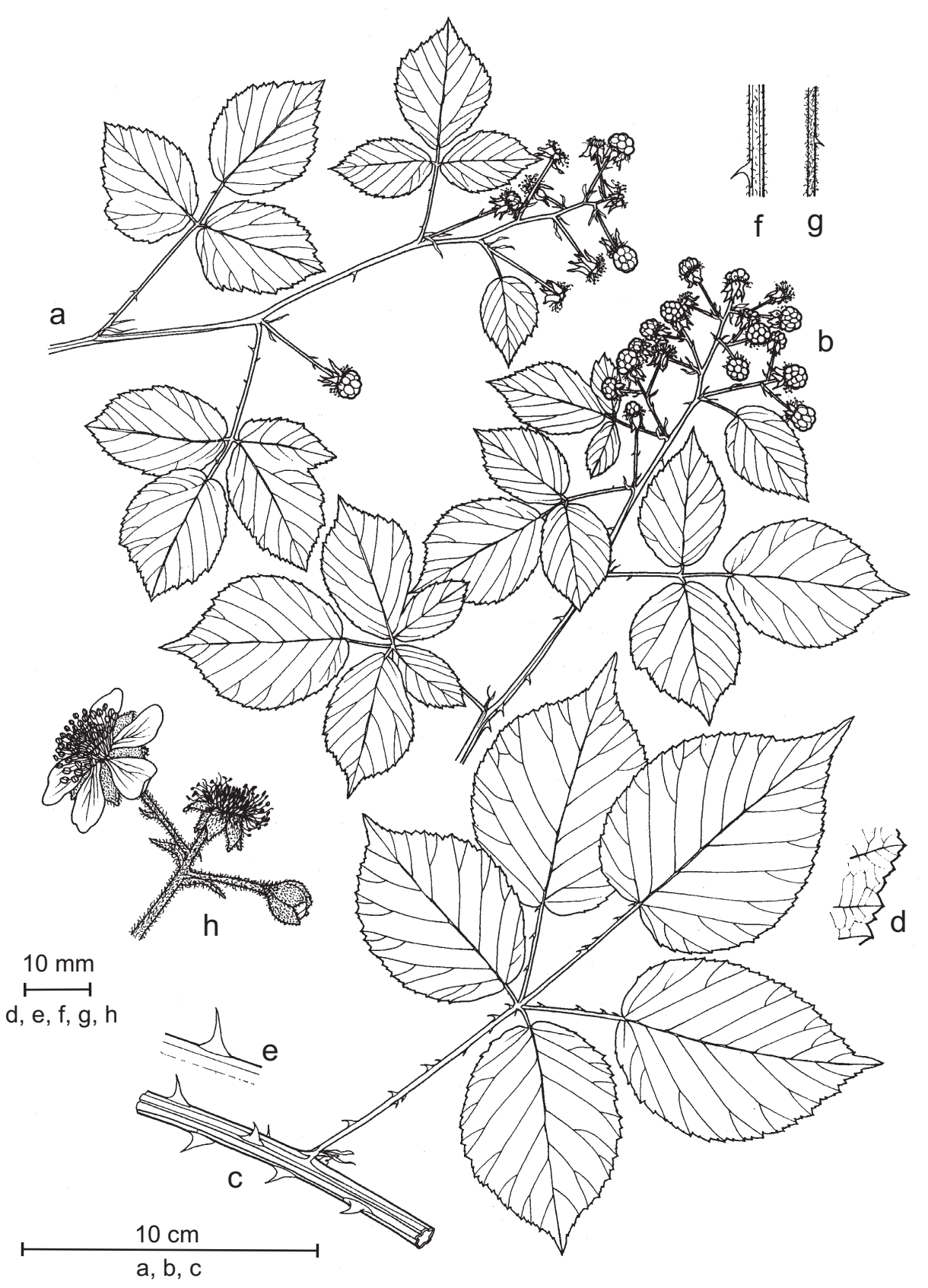

Fig. 2. Rubus ambrosius: $\mathrm{a}-$ racemose infructescence $(\mathrm{bar}=10 \mathrm{~cm}) ; \mathrm{b}-$ paniculate infructescence $(\mathrm{bar}=10 \mathrm{~cm})$; $\mathrm{c}$ - leaf $(\mathrm{bar}=10 \mathrm{~cm}) ; \mathrm{d}$ - indentation of terminal leaflet margin $(\mathrm{bar}=10 \mathrm{~mm}) ; \mathrm{e}-$ detail of first-year branch with prickle $(\mathrm{bar}=10 \mathrm{~mm}) ; \mathrm{f}-$ detail of inflorescence axis $(\mathrm{bar}=10 \mathrm{~mm}) ; \mathrm{g}-$ detail of peduncle $(\mathrm{bar}=10 \mathrm{~mm}) ; \mathrm{h}-$ detail of flowers $(\mathrm{bar}=10 \mathrm{~mm})($ del. A. Skoumalová). 


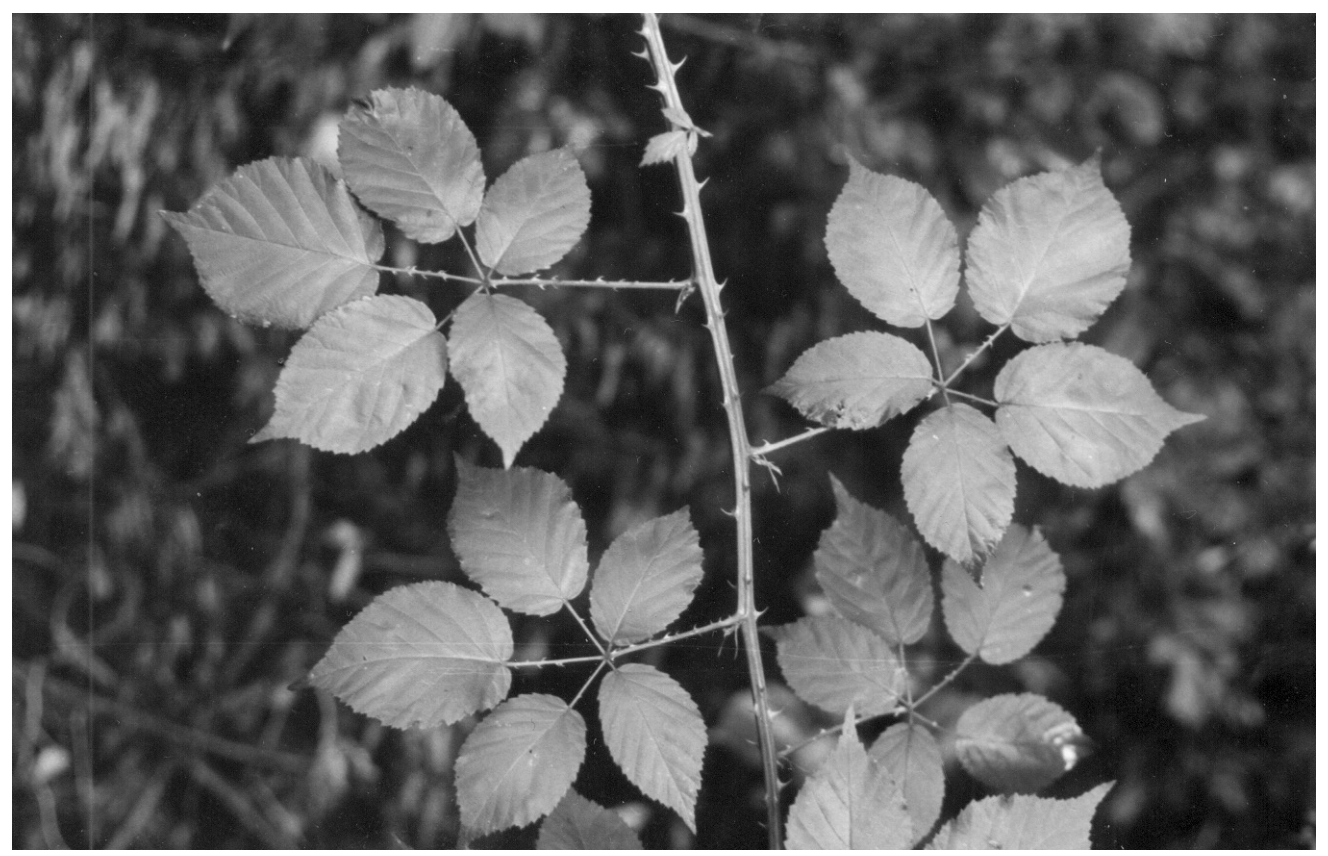

Fig. 3. First-year branch of Rubus ambrosius (locality: Central Moravia, Chropyně village near Kroměříž town).

Etymology: The specific epithet of Rubus ambrosius refers to the majestic appearance of the species.

\section{Description (see also Figs. 1-4)}

Usually robust shrubs, (1-)1.5-2.5 m tall, without stalked glands. First-year stems initially erect, later highly arcuate, often branched, without rooting tips in autumn, stout, $(5-) 7-13(-15) \mathrm{mm}$ in diameter, markedly deeply furrowed, green or (in sunny sites) suffused purple, usually glabrous (with $0-1$ hair per $1 \mathrm{~cm}$ of stem side length), with (40-)70-180(-230) sessile or subsessile glands per $1 \mathrm{~cm}$ of stem side. Prickles $(2-) 3-6(-7)$ per $5 \mathrm{~cm}$ of stem length, \pm uniform, (6-)7-11(-12) mm long, slender, laterally compressed and broadened at (5-)6-8(-9) mm long base, straight or indistinctly curved, patent to somewhat declining, yellowish green or purplish with yellowish tips.

Leaves 5 -foliolate, palmate, flat, usually with non-overlapping leaflets, green to dark green, sparsely appressed hairy or almost glabrous above (i.e. with $(0-) 3-15(-20)$ simple hairs per $1 \mathrm{~cm}^{2}$ ), green or (in sunny sites) slightly greyish beneath, with numerous rather short, subpatent, somewhat intertwined hairs, distinctly to softly hairy to the touch, but without stellate hairs. Petiole (7-)8-10(-12) cm long, most frequently longer than or as long as lower leaflets (petiole (90-)100-130(-200)\% as long as lower leaflets), only in the lower part sulcate, with scattered patent hairs and (5-)9-16(-20) distinctly curved, most often \pm hooked prickles. Stipules filiform to narrowly linear-lanceolate, $0.5-1.0 \mathrm{~mm}$ wide. Terminal leaflet usually with markedly long petiolule (petiolule (35-)43-56(-60)\% as long as leaflet lamina), ovate, broadly oblong to suborbicular (sometimes to almost pentagonal), always 


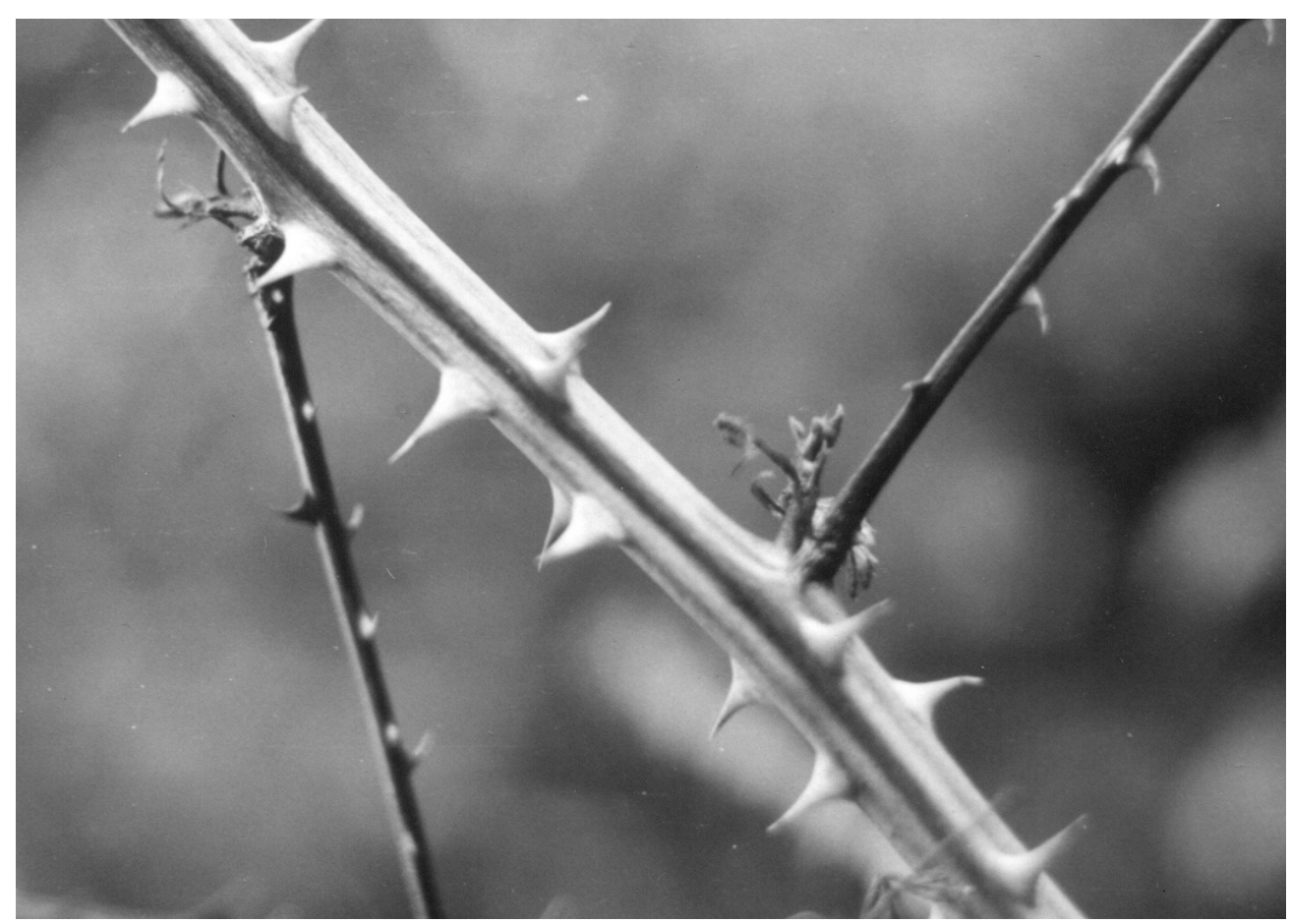

Fig. 4. Detail of first-year branch of Rubus ambrosius (locality: Central Moravia, Chropyně village near Kroměříz town).

distinctly cordate at base, with \pm abrupt, relatively long ((13-)15-24(-27) $\mathrm{mm})$ apex. Leaflet margin \pm flat, indentation \pm regular, with teeth often broader than long, with incisions (1-)1.5-2.5 mm deep; lateral leaflets most often distinctly smaller than the terminal leaflet. Lower leaflets with (3-)5-9(-12) mm long petiolules.

Early flowering inflorescence racemose, usually shortly cylindrical, leafless at the apex (leafless part 4-10 cm long), with 3-foliolate leaves below; leaves appressed hairy above (with 15-30 hairs per $1 \mathrm{~cm}^{2}$ ), usually green and \pm densely hairy beneath; terminal leaflet most often obovate, with an acuminate apex 6-11 mm long, leaflet margin usually distinctly (sometimes grossly) periodically serrate, with incisions $2-4(-5) \mathrm{mm}$ deep; inflorescence axis straight to slightly flexuose, frequently somewhat furrowed, with scattered patent simple hairs; prickles $0-2(-3)$ per $5 \mathrm{~cm}$ of axis length, usually hooked, $2-4 \mathrm{~mm}$ long, with $3-5 \mathrm{~mm}$ long base; pedicels $2-6 \mathrm{~cm}$ long, erecto-patent, rather densely pilose (without stellate hairs), with scattered sessile glands, with $0-3(-5) \pm$ falcate, $1-2(-3) \mathrm{mm}$ long prickles. Serotinous inflorescence of different appearance, paniculate, usually shortly pyramidal, distally with $1-13 \mathrm{~cm}$ long leafless part; lower inflorescence leaves 5-foliolate, upper 3-foliolate and/or simple, only sparsely hairy to almost glabrous above (with (0-)3-15 hairs per $1 \mathrm{~cm}^{2}$ ), often (especially in sunny sites) slightly greyish beneath, densely hairy, with subpatent intertwined hairs; shape and serration of terminal leaflets like those of first-year stems; prickles on inflorescence axis $2-7 \mathrm{~mm}$ long, usually falcate, $2-7$ per $5 \mathrm{~cm}$ axis length; pedicels $0.7-2.0$ cm long. 


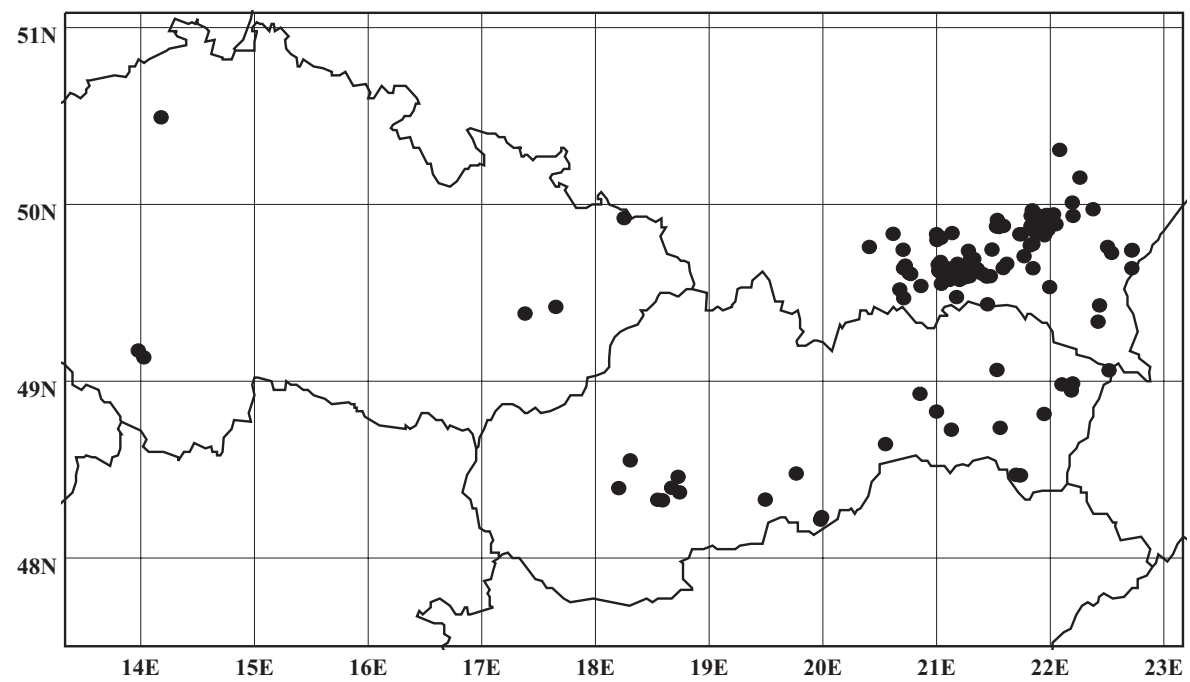

Fig. 5. Hitherto known distribution of Rubus ambrosius documented by herbarium specimens.

Flowers most often middle-sized, (1.5-)2.0-2.7(-3.0) $\mathrm{cm}$ on average. Sepals often with short tip (but in terminal flowers sometimes prolonged, with lanceolate appendix), reflexed after anthesis, greyish green (densely subappressed hairy) on the back, with white tomentose margins, without prickles. Petals pinkish white to light pink, (7-)9-13 mm long, 6-8 mm wide, broadly elliptic to obovate, not overlapping. Stamens longer than styles, filaments white; anthers glabrous. Ovaries glabrous or with solitary hairs; styles greenish. Receptacle glabrous to sparsely pilose. Fruit small to middle-sized, semiglobose to globose, with (5-)10-30(-35) blackish drupelets. Flowering V-VII(-VIII).

\section{COMPARISON WITH SIMILAR TAXA}

Within the subsection Rubus the species discussed surely belongs to the series Rubus, subseries Rubus (classification according to WEBER 2000). R. ambrosius is closely related to $R$. sulcatus VEST, but differs from it by more deeply furrowed stems, longer prickles on first-year stems, longer petioles, more prickly petioles, densely (to softly) hairy leaves beneath and by blunter leaf margin serration with incisions only (1-) 1.5-2.5 mm deep. The differences between the two taxa are summarized in the Table 1. Both species can occur together in the same locality.

Further chance of confusion represents Rubus perrobustus HOLUB, particularly in the eastern part of Central Europe where the distribution areas of both species overlap. $R$. perrobustus is most often regarded as a member of the subsection Rubus, although it in fact occupies an intermediate position between Rubus subsect. Rubus and Rubus ser. Discolores (P.J. MUELLER) FOCKE. Also this taxon can grow together with $R$. ambrosius in some sites (particularly in Slovakia). It differs from $R$. ambrosius in its first-year stems rooting in autumn, shorter (6-8 $\mathrm{mm}$ long) stem prickles, distinctly periodic indentation of leaflet margins and absence of early flowering racemose inflorescences. 
Table 1. Morphological differences between Rubus sulcatus and R. ambrosius.

Character
Branching of first-year stems
Form of stem sides
Colour of first-year stems (in sunny sites)
Number of (sub)sessile glands per $1 \mathrm{~cm}$
stem side length
Length of prickles (on first-year stems)
Number of prickles per 5 cm stem length
Indument of lower leaf surface

\section{Petiole length}

Petiole length : lower leaflets length ratio

Number of petiole prickles

Length of terminal leaflet petiolule : length of its lamina ratio

Shape of terminal leaflet base

Length of terminal leaflet apex

Indentation of leaflet margin

Depth of leaf margin incisions

Characteristic of lower surface of uppermost leaves in the serotinous (paniculate) inflorescence

Flowers diameter

Characteristic of outside sepals surface

Petals length

Size and shape of collective fruit in early matured (i.e. racemose) infructescence

Number of drupelets per fruit in racemose infructescence
R. sulcatus
R. ambrosius

Stems usually not branched

Stouter stems often branched

Stem sides sulcate to almost flat

Stem sides very deeply sulcate

Stems suffused (dark) red-brown

Stems suffused purplish

$(0-) 10-50(-80)$

$(40-) 70-180(-230)$

(5-)6-9(-10) mm

(6-)7-11(-12) mm

$(1-) 2-4(-6)$

Lower leaf surface usually with sparsely distributed patent hairs, most often only slightly hairy to the touch

(2-)3-6(-7)

Lower leaf surface with numerous subpatent, somewhat intertwined hairs, distinctly to softly hairy to the touch

\section{(5-)6-8(-10) cm}

Petiole usually shorter than lower (7-)8-10(-12) cm leaflets (petiole (65-)70-95(-110)\% as long as lower leaflets)

Petiole longer than or as long as lower leaflets (petiole (90-)100$-130(-200) \%$ as long as lower leaflets)

(4-)5-10(-12)

(5-)9-16(-20)

Petiolule (30-)35-47(-50)\% as long as leaflet lamina

Petiolule (-35)43-56(-60)\% as long as leaflet lamina

Distinctly cordate to sometimes almost \pm truncate

(16-)19-28(-30) mm

Always distinctly cordate

(13-)15-24(-27) mm

Regular to periodic, with teeth prolonged and very acute

\pm regular, with teeth often broader than long, not very acute

(1.5-)2-4 mm

Lower leaf surface usually green, scattered to rather densely hairy, with patent hairs

(2-) $2.5-4 \mathrm{~cm}$

Sepals almost green, with scattered longer hairs

(8-)10-17 mm

Fruit often large, ovate to oblong cylindrical

(10-)20-45(-50)
(1-)1.5-2.5 mm

Lower leaf surface often slightly greyish, densely hairy, with subpatent intertwined hairs

(1.5-)2-3 cm

Sepals greyish green, densely subappressed hairy

(7-)9-13 mm

Fruit small to middle-sized, semiglobose to globose

(5-)10-30(-35) 
Another somewhat similar species, $R$. graecensis MAURER, has similarly deeply furrowed stems and leaflets with regularly serrate margins, densely hairy beneath, but it strongly differs in having first-year stems only with $0-1$ shorter prickle per $5 \mathrm{~cm}$ length, shorter $(0-3 \mathrm{~mm})$ petiolules of lower leaflets and always white flowers with shorter stamens.

Very deeply furrowed stems, analogous to those in $R$. ambrosius, are also characteristic of $R$. canaliculatus P.J. MUELLER from the southwestern part of Germany and adjacent regions (see WEBER 1995: 354, 355). However, the latter species has somewhat shorter (6-8 mm) stem prickles, less prickly petioles (usually only $3-8$ ), shorter (3-5 mm) petiolules of lower leaflets, only paniculate inflorescences and styles usually reddish at the base.

From among the species known in the Czech Republic, $R$. barrandienicus HoLUB differs from $R$. ambrosius by smaller (3-6 mm long) stem prickles, sparsely hairy leaves beneath, narrower lower leaflets always distinctly longer than the petiole and by white flowers with shorter stamens.

\section{HITHERTO KNOWN GEOGRAPHICAL DISTRIBUTION (SEE ALSO FIG. 5)}

Rubus ambrosius is a widely distributed bramble species (in the sense of WEBER 1996: 377). It has been found in the Czech Republic (rare in both Bohemia and Moravia), Slovakia (scattered, but possibly more common) and in the south-eastern part of Poland (quite common). It is possible that it occurs also in N Hungary, W Belorussia and W Ukraine. R. ambrosius was first (in 1992) recognized in SE Slovakia (Zemplínske vrchy hills), and the knowledge of its much more extensive distribution is a result of later exploration. For herbarium specimens examined - see Appendix).

\section{ECOLOGY}

Rubus ambrosius belongs to a rather thermophilous group of brambles obviously preferring nutrient rich, only slightly acidic to basic, not water logged soils. In contrast to the mainly nemophilous $R$. sulcatus, it is a semi-forest to sometimes thamnophilous bramble. It usually prefers half shaded sites and most often occurs along forest roads, on woodland margins, in open patches in forest, on clearings and among shrubs, sometimes in wayside thickets. It often grows (especially in the southern half of Slovakia) together with some representatives of the series Discolores (e.g. R. montanus LEJ., $R$. austroslovacus TRÁVNÍČEK, $R$. parthenocissus TRÁVNÍČEK et HOLUB) or with $R$. perrobustus.

Acknowledgements: We thank all who lent us herbarium material for revision, namely M. Dančák (Olomouc), P. Havlíček (Praha), V. Žíla (Strakonice), P. Kusák (Zlín), Ł. Łuczaj (Rzepnik) and M. Szewczyk (Jaworzna). The study was supported by the Grant Agency of the Czech Republic (Grant no. 206/99/0771) and the Committee for Scientific Research of Poland (Grant no. 6 P04G 031 16).

\section{REFERENCES}

FUTÁK J. (1966): Fytogeografické členenie Slovenska (Phytogeographical division of Slovakia). In: FUTÁK J. (ed.), Flóra Slovenska (Flora of Slovakia) 1, Vydavatel'stvo Slovenskej akadémie vied, Bratislava, pp. 353-358.

HOLUB J. (1992): A preliminary checklist of Rubus species occuring in the Czech Republic. Preslia 64: 97-132. 
HOLuB J. (1999): Předběžný Červený seznam ostružiníků České republiky (A preliminary Red List of Rubus species of the Czech Republic). Zprávy České Bot. Společ. 34: 1-19.

Holub J. \& PRochÁzKA F. (2000): Red List of vascular plants of the Czech Republic - 2000. Preslia 72: $187-230$.

Holub J. \& TRÁVNíČEK B. (1998): Rubus L. (Rosaceae), ostružina (Rubus L. (Rosaceae), bramble). In: MARHOLD K. \& HINDÁK F. (eds.), Checklist of non-vascular and vascular plants of Slovakia, Veda, Bratislava, pp. 601-603.

KONDRACKI J. (2000): Geografia regionalna Polski (Regional Geography of Poland). Wydawnictwo Naukowe PWN, Warszawa.

MATZKE-HAJEK G. (1997): Zur Evolution und Ausbreitung apomiktischer Rubus-Arten (Rosaceae) in Offenland-Ökosystemen. Bull. Geobot. Inst. ETH 63: 33-44.

PROCHÁZKA F. (ed.) (2001): Černý a červený seznam rostlin České republiky (stav v roce 2000) (Black and Red List of Vascular Plants of the Czech Republic - 2000). Přiroda 18: 1-166.

SKALICKÝ V. (1988): Regionálně fytogeografické členění (Regional phytogeographical division). In: HEJNÝ S. \& SLAvíK B. (eds.), Květena České socialistické republiky (Flora of the Czech Socialist Republic) 1, Academia, Praha, pp. 103-121.

TRÁVNíČEK B. \& HAVlíčEK P. (2002): 16. Rubus L. - ostružiník (16. Rubus L. - bramble). In: KUBÁT K., Hrouda L., ChrteK J. jun., KAPlan Z., KirSchner J. \& ŠTĚPÁNEK J. (eds.), Klič ke květeně České republiky (Key to the flora of the Czech Republic), Academia, Praha, pp. 329-376.

WeBER H.E. (1995): 4. Rubus. In: HeGI G., Illustrierte Flora von Mitteleuropa, 4/2A, Ed. 3, Blackwell Wissenschafts-Verlag, Berlin, Oxford etc., pp. 284-595.

WEBER H.E. (1996): Former and modern taxonomic treatment of the apomictic Rubus complex. Folia Geobot. Phytotax. 31: 373-380.

WEBER H.E. (1999): The present state of taxonomy and mapping of blackberries (Rubus) in Europe. Acta Bot. Fenn. 162: 161-168.

WEBER H.E. (2000): Gliederung der Sommergrünen Brombeeren in Europa (Rubus L. subgenus Rubus subsectio Rubus). Osnabrücker Naturwiss. Mitt. 26: 109-120.

Received 9 August 2004, revision received 24 January 2005, last revision received and accepted 9 May 2005 Encl. Appendix, pp. 431-434 


\section{APPENDIX}

Herbarium specimens examined (distribution map - see Fig. 5)

Czech Republic (Phytogeographical division follows SKALICKÝ 1988)

5b. Roudnické písky: Travčice village near Terezín town, pine wood (with Robinia) S of the vilage, E of a road (HAVLÍČEK 13.X.2001 PRC). - 21b. Hornomoravský úval: Distr. Kroměříž, Chropyně town, along the railway line in the wood of Rasina $2 \mathrm{~km}$ NE of the railway station (TRÁVNíČEK 30.VI.1993 OL; TRÁVNÍČEK 3.IX.1994 OL). - 37e. Volyňské Předšumaví: Střítež village near Volyně town, along the road towards Skály village, 1.2 $\mathrm{km}$ E of the village (ŽílLA 15.IX.1996 herb. ŽíLA). - Distr. Strakonice, Štětín village, wood S of the road $0.7 \mathrm{~km}$ NWW of the village (TRÁVNÍČEK 16.VIII.1996 OL). - 76a. Moravská brána vlastní: Sovadina village, in the wood along the road to Bystřice pod Hostýnem town, $1.5 \mathrm{~km} \mathrm{~S}$ of the village (TRÁVNíČEK 16.VII.2002 OL). 83. Ostravská pánev: Šilheřovice village near Ostrava town, bushes along the road towards Markvartovice village (TRÁVNíČEK 5.VIII.1998 OL), the holotype. - Šilheřovice village near Hlučín town (HOLUB 20.VII.1989 PRA).

\section{Slovakia (Phytogeographical division follows FUTÁK 1966)}

2. Ipel'sko-rimavská brázda: Luboreč village near Lučenec town, between Lysec hill (716.4 m) and the village (HOLUB 10.VII.1983 PRA). - Hanáčka village near Fil'akovo town, along the forest pathway at the SW foothill of Ragáč hill (536.6 m) (TRÁVNíČEK 30.VII.1993 OL). - Ragáč hill (536.6 m) near Lučenec town, the valley below the hill (HOLUB 6.VII.1983 PRA). - 3. Slovenský kras: Jovice village near Rožňava town, bushes along the brook on the N edge of the village (TRÁVNíČEK 28.VI.1999 OL). - 8. Východoslovenská nížina: Trnava pri Laborci village near Michalovce town, shrubs along a rural road at the E village margin (TRÁVNÍČEK 24.VI.2004 OL). - Zemplínske vrchy hills, Vel'ká Trňa village, wood clearing in the valley $0.6 \mathrm{~km} \mathrm{E}$ of the village (TRÁVNíČEK 8.VIII.1992 OL). - Zemplínske vrchy hills, Cejkov village, along the forest way in the valley 0.5 $\mathrm{km}$ N of the Bocianí vrch hill (258 m) (TRÁVNíČEK 8.VIII.1992 OL). - Zemplínske vrchy hills, Cejkov village, along the forest way in the valley $0.7 \mathrm{~km} \mathrm{NW}$ of the Bocianí vrch hill (258 m) (TRÁVNíČEK 8.VIII.1992 OL). 12. Tríbeč: Klátova Nová Ves village near Partizánske town, valley of the brook $0.5 \mathrm{~km} \mathrm{SW}$ of the gamekeeper's lodge of Cibajky, S of the village (TRÁVNíČEK 8.VII.1994 OL). - Jelenec village near Nitra town, on the woodland path $0.8 \mathrm{~km}$ NWW of Jelenec reservoir NW of the village (TRÁVNíČEK 5.VII.2003 OL). 14e. Štiavnické vrchy: Voznica village near Banská Štiavnica town, along the road in the valley of Richnava brook on E edge of the village (TRÁVNÍČEK 9.VII.1997 OL). - Brehy village near Banská Štiavnica town, along the road in the valley 1.5-2 km SEE of the village, SW of Chlm hill (TRÁVNíČEK 6.VII.2003 OL; ŽÍLA 6.VII.2003 herb. ŽílLA). - Pukanec village near Banská SStiavnica town, along the road towards Brehy village, ca. $2 \mathrm{~km}$ N of the village (TRÁVNÍČEK 6.VII.2003 OL; Ž́́LA 6.VII.2003 herb. ŽÍLA). - Hronský Beňadik village, by the brook $1.5 \mathrm{~km}$ E of railway station (TRÁVNíčEK 18.VII.1995 OL). - Hronský Beňadik village, between Psiare settlement and the village (HOLUB 11.VI.1981 PRA). - 15. Slovenské rudohorie: Nižný Klátov village near Košice town, in the scrub near the branch of the road towards Bukovec reservoir, $0.8 \mathrm{~km} \mathrm{SWW} \mathrm{of} \mathrm{the} \mathrm{village}$ (TRÁVNÍČEK 9.VII.2003 OL; ŽÍLA 9.VII.2003 herb. ŽÍLA). - Kojšov village near Gelnica town, along the rural road $0.5 \mathrm{~km}$ NE of the village (TRÁVNÍČEK 6.VII.2000 OL). - Úhorské village near Poltár town, near the water reservoir $1 \mathrm{~km}$ SE of the village (TRÁVNÍČEK 19.VII.1995 OL). - 18. stredné Pohornádie: Branisko hills, Krompachy town, slope above the Hornád river $1.3 \mathrm{~km} \mathrm{NWW}$ of the railway station (TRÁVNÍČEK 4.VII.2000 OL). - 19. Slanské vrchy: Dargov village near Trebišov town, along the road $1.5 \mathrm{~km} \mathrm{~W}$ of the village (TRÁVNíČEK 19.VII.1995 OL). - 20. Vihorlat: Snina town, along the road towards the Sninský Kameň Mt. (1005 m), approx. 400 m a.s.l. (KUSÁK 22.VII.1993 OL). - 30c. Nízke Beskydy: Durd'oš village, wood margin near the road towards Giraltovce town close to the branch of the forest way, $2.6 \mathrm{~km} \mathrm{NEN} \mathrm{of} \mathrm{the} \mathrm{village}$ (TRÁVNÍČEK 10.VII.2003 OL; ŽÍLA 10.VII.2003 herb. ŽíLA) - Belá nad Cirochou village near Snina town, bushes and clearings $1 \mathrm{~km} \mathrm{~N}$ of the village, $240 \mathrm{~m}$ a.s.1. (DANČÁK 1.IX.2002 OL). - 31. Bukovské vrchy: Nová Sedlica village, bushes and wood margins on the N edge of the village, $450 \mathrm{~m}$ a.s.l. (DANČÁ 3.IX.2002 OL). Snina town, Magurica hill E of the town (HOLUB 4.VII.1978 PRA).

Poland (Phytogeographical division follows KONDRACKI 2000)

512.48 Kolbuszowa Plateau: Kamień: Podlesie, young pine secondary wood (OKLEJEWICZ 8.VIII.1992 herb. OKLEJEWICZ). - Rakszawa village, roadside ditch (OKLEJEWICZ 19.VII.2000 herb. OKLEJEWICZ). - 
513.49 Beskid Wyspowy Mts.: Młynne - Chromanie, hornbeam forest, altitude $410 \mathrm{~m}$ (SZEWCZYK 23.IX.1998 KRA). - 513.53 Sącz Valley: Naściszowa village near Nowy Sącz, Abies alba-Quercus robur forest edge (OKLEJEWICZ 25.IX.2000 KRA). - Nowy Sącz: Barska Street, in an Alnus incana thicket on the concreted bank of a stream (OKLEJEWICZ 25.IX.2000 KRA). - 513.54 Beskid Sądecki Mts.: Wola Krogulecka village, Fagus sylvatica forest edge, along lane (OKLEJEWICZ 30.VIII.2000 KRA). - Głębokie, in a steep pasture, on the edge of Frangula alnus scrub (OKLEJEWICZ 30.VIII.2000 KRA). - 513.62 Ciężkowice Foothills: Cisie village, Abies alba forest edge (OKLEJEWICZ 26.VIII.2000 KRA). - Krzyżowa Mountain, along a lane, abandoned farmland overgrown by Nardus stricta and Hieracium pilosella (OKLEJEWICZ 26.VIII.2000 KRA). - Kołkówka village, field margin, (OKLEJEWICZ 16.IX.1999 KRA). - Dąbry village, Pinus sylvestris forest edge (OKLEJEWICZ 26.VIII.2000 KRA). - 513.63 Strzyżów Foothills: a hill about $3.5 \mathrm{~km} \mathrm{~N}$ from Czudec (altitude $377 \mathrm{~m}$ ), along a lane, on the edge of a Fagus sylvatica forest (OKLEJEWICZ 13.VII.2000 KRA). - Wola Czudecka village, Pinus sylvestris-Quercus robur forest edge (OKLEJEWICZ 13.VII.2000 KRA). - Klonowa Mountaim, Betula pendula-Quercus robur forest edge (OKLEJEWICZ 16.VII.2001 KRA). - Huta Gogołowska village, along a lane, on the edge of a Betula pendula thicket (OKLEJEWICZ 16.VII.2001 KRA). - Huta Gogołowska village, along a lane, on the edge of a Fagus sylvatica-Pinus sylvestris forest (OKLEJEWICZ 3.VIII.2000 KRA). - Stępina village, in a grazed clearing in a Alnus glutinosa thicket (OKLEJEWICZ 3.VIII.2000 KRA). - 513.64 Dynów Foothills: Albigowa: Honie near Łańcut, along a road, on the Quercus robur-Pinus sylvestris forest edge (OKLEJEWICZ 21.IX.2000 KRA). - Zawisłocze, Birch-pine-fir forest (OKLEJEWICZ 20.VIII.1999 KRA). - Podgóry, beech forest margin (OKLEJEWICZ 18.VIII.1999 KRA). - Rzeki, fir forest margin (OKLEJEWICZ 10.VII.1999 KRA). Przylasek near Rzeszów, Fagus sylvatica forest edge (OKLEJEWICZ 21.VII.2000 KRA). - Hermanowa village near Rzeszów, Fagus sylvatica forest edge, along a lane (OKLEJEWICZ 21.VII.2000 KRA). - Hermanowa Czerwonki near Rzeszów, Pinus sylvestris-Betula pendula forest edge (OKLEJEWICZ 25.VIII.2000 KRA). Lubeńki near Rzeszów, the edge of a small oak wood among fields (OKLEJEWICZ 5.VII.2001 KRA). - Lubenia: Maternówka, wayside thickets (ZIELIŃSKI 26.VIII.1999 KOR). - Straszydle: Bania near Rzeszów, Pinus sylvestris-Quercus robus-Larix decidua forest edge (OKLEJEWICZ 20.X.2000 KRA). - Kanada, forest edge (OKLEJEWICZ 1992 KRA). - Podsośnina, by the field road, $300 \mathrm{~m}$ a.s.l. (OKLEJEWICZ 24.IX.1997 KRA). Gwoźnica Dolna, beech-fir forest (OKLEJEWICZ 21.VIII.1999 KRA). - Siedleczka, W part of village, along a lane, on the edge of an orchard (OKLEJEWICZ 10.IX.1999 KRA). - Żarnowa village near Strzyżów, along a lane, altitude 350 m (OKLEJEWICZ 24.IX.1997 KRA). - Małówka village, the edge of a wooded patch with Carpinus betulus (OKLEJEWICZ 21.X.1997 KRA). - Baryczka, pastured waste places, $340 \mathrm{~m}$ a.s.l. (OKLEJEWICZ 28.VII.1998 KRA). - Zagórze, W part, Abies alba forest edge, fir forest margin (OKLEJEWICZ 13.X.1999 KRA). - Straszydle: Podlas, field margin (OKLEJEWICZ 12.X.2000 KRA). - Straszydle: Zimny Dział, field margin (OKLEJEWICZ 26.IX.2000 KRA). - Straszydle: Nalepki, Abies alba forest edge (OKLEJEWICZ 20.X.2000 KRA). - Życzniak, the edge of a wooded patch with Populus tremula (OKLEJEWICZ 26.IX.2000 KRA). - Wilczak Błażowski, Abies alba-Fagus sylvatica forest edge (OKLEJEWICZ 26.IX.2000 KRA). - Wilczak Leczański, Fagus sylvatica forest edge (OKLEJEWICZ 26.IX.2000 KRA). - Blizianka (Rzym), coppice with Alnus glutinosa (OKLEJEWICZ 21.VIII.1999 KRA). - Blizianka, NE part of the village, Abies alba-Pinus sylvestris forest edge (OKLEJEWICZ 12.X.2000 KRA). - Lecka village, along a road, in scrub with Salix caprea (OKLEJEWICZ 12.X.2000 KRA). - Czarnotówki, along a lane (OKLEJEWICZ 21.VIII.1999 KRA; ZIELIŃSKI 25.VIII.1999 KOR). - Zatyle near Domaradz, Fagus sylvatica forest edge (OKLEJEWICZ 2.IX.1999 KRA). - Wysoka Strzyżowska: Stodolina near Strzyżów, abandoned farmland along a gravel track (OKLEJEWICZ 27.VIII.2001 KRA). - Brzeżańska Mountain, along a road in Abies alba forest (OKLEJEWICZ 27.VIII.2001 KRA). - Kiczora Mountain, pine forest margin (OKLEJEWICZ 5.X.1998 KRA). - Krasna Mała, coppice margin with Alnus glutinosa (OKLEJEWICZ 5.X.1998 KRA). - Węlówka, wayside (ZIELIŃSKI 25.VIII.1999 KOR). - Krosno, Mountain Korona, field margin (ŁUCZAJ 29.VIII.1992 herb. Łuczaj). - 513.65 Przemyśl Foothills: Brzuska, along a road in a pine forest (OKLEJEWICZ 13.IX.1999 KRA). - Huta Brzuska, abandoned farmland (OKLEJEWICZ 8.VIII.2001 KRA). - Witoszyńce near Przemyśl, Pinus sylvestris-Fagus sylvatica forest edge (OKLEJEWICZ 4.VII.2001 KRA). - Winna Mountain near Przemyśl, Pinus sylvestris-Fagus sylvatica forest edge (OKLEJEWICZ 28.VI.2001 KRA). - Nowosiółki Dydyńskie, abandoned farmland and scrub, along a lane (OKLEJEWICZ 9.X.2000 KRA). - 513.67 Rożnów Foothills: Rezerwat Bukowiec, along a road in Carpinus betulus forest (OKLEJEWICZ 24.VIII.2001 KRA). - Tabaszowa village, along a lane in Fagus sylvatica forest (OKLEJEWICZ 22.VIII.2001 KRA). - 513.66 Obniżenie Gorlickie: Sokół village near Gorlice, along a lane in Quercus robur forest (OKLEJEWICZ 19.VII.1989 KRA). - Siary village near Gorlice, oldfield (OKLEJEWICZ 14.VII.1989 KRA). - Ropica Polska near Gorlice, Carpinus betulus forest edge (OKLEJEWICZ 13.VIII.2001 KRA). - Siary village near Gorlice, oldfield (OKLEJEWICZ 14.VII.1989 KRA). - Belna village near Biecz, Pinus sylvestris plantation (OKLEJEWICZ 27.VII.1989 KRA). - Wójtowa village, along a field track (OKLEJEWICZ 30.VI.2001 KRA). - 513.67 Jasło-Krosno Valley: Jasło Sobniów (Rzemieślnicza Street), along railway tracks 
(OKLEJEWICZ 16.VIII.2001 KRA). - Kopytowa village, Carpinus betulus forest edge (OKLEJEWICZ 16.IX.1989 KRA). - Poraj (ZIELIŃSKI 18.VIII.1988 KOR). - Widacz, NW part of village near Krosno, a wooded patch with Pinus sylvestris and Salix aurita (OKLEJEWICZ 31.VIII.1987 KRA). - 513.68 Jasło Foothills: Pagorzyna village, along a road in Abies alba forest (OKLEJEWICZ 30.VI.2001 KRA). - 513.71 Beskid Niski Mts.: Bieśnik village, along a lane (OKLEJEWICZ 1.VII.1995 KRA). - Wyskitna village, scrub on the field margin (OKLEJEWICZ 23.IX.1999 KRA). - Zielona Mountain, on the egde of a birch-aspen thicket on the edge of a firwood (OKLEJEWICZ 23.IX.1999 KRA). - Obłazy village near Nowy Sącz, Abies alba-Quercus robur forest edge (OKLEJEWICZ 25.IX.2000 KRA). - Mystków: Zabrzeziny near Nowy Sącz, Pinus sylvestris forest edge, along a lane (OKLEJEWICZ 25.IX.2000 KRA). - Gródek village near Grybów, dry roadside (OKLEJEWICZ 30.VI.1994 KRA). - Podlesie village near Grybów, forest edge, altitude 550 m (OKLEJEWICZ 23.IX.1996 KRA) and along a field track (OKLEJEWICZ 30.VI.2001 KRA). - Szklarki (about $500 \mathrm{~m}$ NW of Szymbark Łegi), scrub between field (OKLEJEWICZ 5.VI.2000 KRA). - Szymbark Łegi, in thickets along a lane (OKLEJEWICZ 27.VII.1996 KRA) and Abies alba-Fagus sylvatica forest edge (OKLEJEWICZ 5.VI.2000 KRA). - Szymbark W part of village, along a field track (OKLEJEWICZ 13.VIII.1994 KRA). - Bukowa village near Szymbark village, the edge of scrub, along a village road, altitude 390 m (OKLEJEWICZ 23.IX.1996 KRA). - Ropa, S part of the village (between Gorlice and Grybów), Fagus sylvatica forest edge (OKLEJEWICZ 2.VIII.1991 KRA). - Sękowa village near Gorlice, by a river, on the edge of an Alnus incana thicket and by the road (OKLEJEWICZ 23.VIII.1994 KRA). - Zagórze Mountain near Sękowa village, forest edge, altitude 390 m (OKLEJEWICZ 22.VII.1997 KRA). - Miejska Góra Mountain near Szymbark village, forest edge (OKLEJEWICZ 9.VIII.1995 KRA). - Bielanka, N part by the forest road (OKLEJEWICZ 4.VII.1995 KRA). - Obocz Mountain, along a field track (OKLEJEWICZ 23.VIII.1996 KRA). - Magura Małastowska, slopes from the side of Owczary village, along a lane in a beech-fir forest (OKLEJEWICZ 4.VII.1997 KRA). - Łysiec Mountain, along a field track (OKLEJEWICZ 28.VII.1995 KRA). - Łysula Mountain, forest edge (OKLEJEWICZ 28.VII.1995 KRA). - Between Kraczeniówka village and Podlesie village, a clearing in beechwood (OKLEJEWICZ 6.VII.1996 OL). Dubnakowa Mountain, forest edge (OKLEJEWICZ 31.VIII.1995 KRA). - Bednarka village, scrub along dirt track (OKLEJEWICZ 2.VIII.1994 KRA). - Męcina Mała village, scrub along lane (OKLEJEWICZ 28.VII.1995 KRA). - Wapienne village, scrub on a forest edge (OKLEJEWICZ 3.VIII.1994 KRA). - Wapienne, SE part of village, by a stream, on the edge of thicket (OKLEJEWICZ 3.VII.1994 KRA). - Brusy Mountain, a recently felled beechwood (OKLEJEWICZ 24.VII.1995 KRA). - Dragaszów village, roadside (OKLEJEWICZ 5.X.1994 KRA). Ropica Górna village, a scrub (OKLEJEWICZ 20.IX.1991 KRA). - Bodaki, scrub along a field track (OKLEJEWICZ 5.VIII.1994 KRA). - Łabowa, along a field track (OKLEJEWICZ 9.IX.2003 herb. OKLEJEWICZ). - Jaszkowa, roadside (OKLEJEWICZ 21.VI.1994 KRA). - Kiczera Wielka Mountain (between Florynka, Polany and Brunary), forest margin towards Polany village (OKLEJEWICZ 18.VIII.1995 KRA). - Kiczerka Mountain, forest margin (OKLEJEWICZ 12.VII.1996 KRA). - Perehyba Mountain, a wooded patch with Alnus glutinosa (OKLEJEWICZ 17.VIII.1995 KRA). - Jałszcz Mountain, on the edge of a swampy clearing in an oak-birch wood (OKLEJEWICZ 17.VIII.1995 KRA). - Czerska Mountain (Magurski National Park), forest margin (OKLEJEWICZ 25.VII.1996 KRA). - By the road in an ash forest (OKLEJEWICZ 25.VI.1998 KRA). - Gamracz, along a field road, $440 \mathrm{~m}$ a.s.l. (OKLEJEWICZ 19.VI.1997 KRA). - Mrukowa village, Fagus sylvatica forest edge, along a lane (OKLEJEWICZ 28.VIII.1996 KRA). - Grab village, scrub edge between fields (OKLEJEWICZ 20.IX.1991 KRA). - 522.12 Bieszczady Mts.: Koziniec, thicket along a lane (OKLEJEWICZ 13.VIII.1999 KRA). - Wołkowyja, N part, along a lane, $590 \mathrm{~m}$ a.s.l. (OKLEJEWICZ 21.VIII.1998 KRA).

\section{Rubus ambrosius - Field observations (without herbarium specimens)}

\section{Poland (Phytogeographical division follows KONDRACKI 2000)}

513.62 Ciężkowice Foothills: Zdonia, along a lane (OKLEJEWICZ 22.VIII.2001). - Czerwona Górka, along a lane (OKLEJEWICZ 7.IX.2001). - Borowa, along a lane (OKLEJEWICZ 7.IX.2001). - Bieśnik, Robinia pseudoacacia thicket, along a lane (OKLEJEWICZ 22.VIII.2001). - Zdonia, along a lane (OKLEJEWICZ 22.VIII.2001). - Habalina village, along a lane in Pinus sylvestris forest (OKLEJEWICZ 22.VIII.2001). - Ruda Kameralna village, Fagus sylvatica forest edge (OKLEJEWICZ 22.VIII.2001). - Ruda Kameralna village, along a lane (OKLEJEWICZ 22.VIII.2001). - Górka, along a lane (OKLEJEWICZ 22.VIII.2001). - Borowa, along a lane in Carpinus betulus forest (OKLEJEWICZ 22.VIII.2001). - Roztoka: Brzeziny, along a lane in Betula pendula and Pinus sylvestris forest (OKLEJEWICZ 22.VIII.2001). - Paleśnica, scrub along a lane (OKLEJEWICZ 22.VIII.2001). - 513.61 Rożnów Foothills: Rożnów, along a lane (OKLEJEWICZ 22.VIII.2001). - Bujne, scrub along a lane (OKLEJEWICZ 22.VIII.2001). - Posadowa, along a lane in forest (OKLEJEWICZ 22.VIII.2001). - 
Tabaszowa, along a lane (OKLEJEWICZ 22.VIII.2001). - Rożnów, along a lane (OKLEJEWICZ 22.VIII.2001). Wiesiółka, along a lane (OKLEJEWICZ 22.VIII.2001). - Posadowa, along a lane in forest (OKLEJEWICZ 22.VIII.2001). - Bieśnik, along a lane (OKLEJEWICZ 22.VIII.2001). - Polichty, Abies alba forest edge (OKLEJEWICZ 11.X.2001). - Olszowa, along a lane in Pinus sylvestris forest (OKLEJEWICZ 22.VIII.2001). Jastrzębia, along a lane, on the edge of a Carpinus betulus-Quercus robur forest (OKLEJEWICZ 11.X.2001). Polichty, roadside ditch (OKLEJEWICZ 11.X.2001). - Góra Rosiec, scrub along a lane (OKLEJEWICZ 22.VIII.2001). - Jastrzębia Dolna, thicket edge along a lane (OKLEJEWICZ 11.X.2001). - Bogoniowice, along a lane (OKLEJEWICZ 11.X.2001). - Maśluchowice, roadside bank (OKLEJEWICZ 3.IX.2001). - Szerzyny, Alnus glutinosa-Populus tremula forest edge (OKLEJEWICZ 3.IX.2001). - Przydonica: Glinik, along a lane (OKLEJEWICZ 15.IX.2001). - Biedowa, in scrub along a field track (OKLEJEWICZ 13.VIII.2001). - Łysa Góra (441 m), along a road in Quercus robur-Populus tremula forest (OKLEJEWICZ 3.IX.2001). - Bieśnik, along a lane (OKLEJEWICZ 13.VIII.2001). - Bugaj near Biecz, roadside ditch (OKLEJEWICZ 3.IX.2001). - Bugaj near Biecz, along a lane (OKLEJEWICZ 3.IX.2001). - 513.71 Beskid Niski Mts.: Gródek: Brzezie (OKLEJEWICZ 30.VI.2001). - Jaworze, pasture on the edge of woodland (OKLEJEWICZ 6.VIII.2001). - 513.63 Strzyżów Foothills: Bączałka, Prunus spinosa scrub among fields (OKLEJEWICZ 30.VII.2001). - Brzeziny: Berdechów, along a lane, on the edge of a Alnus glutionsa thicket (OKLEJEWICZ, 16.VII.2001). - Brzeziny: Berdechów, the edge of an overgrown orchard (OKLEJEWICZ 16.VII.2001). - Łopuszka Zachodnia near Strzyżów, by a stream, on the edge of a Alnus glutinosa thicket (OKLEJEWICZ 14.VIII.2001). - Łopuszka Wschodnia near Strzyżów, scrub between fields (OKLEJEWICZ 14.VIII.2001). - Kamienica Górna: Budy, Fagus sylvatica-Betula pendula-Pinus sylvestris forest edge (OKLEJEWICZ 30.VII.2001). - Opacionka: Piaski, along a lane on Quercus robur forest edge (OKLEJEWICZ 18.X.2001). - Between Huta Gogołowska and Kamienica Górna, along a track in a Alnus glutinosa wood (OKLEJEWICZ 16.VII.2001). - Glinik Zaborowski near Strzyżów, forest composed of Alnus glutinosa, Cerasus avium, Populus tremula and Abies alba (OKLEJEWICZ 14.VIII.2001). - 513.64 Dynów Foothills: Hermanowa: Przylasek near Rzeszów, abandoned farmland (OKLEJEWICZ 5.VII.2001). - Straszydle: Stadnina near Rzeszów, along a lane (OKLEJEWICZ 5.VII.2001). - Wola Błażowska, young beech-oak-pine secondary wood (OKLEJEWICZ 20.X.2000). - Oparówka near Strzyżów, scrub edge on abandoned farmland (OKLEJEWICZ 21.VIII.2001). - Podlesie, scrub along a road (OKLEJEWICZ 18.X.2001). - Góra Piaskowa, young birch secondary wood (OKLEJEWICZ 26.VII.2000). - Budy, Abies alba-Quercus robur-Pinus sylvestris-Betula pendula forest edge (OKLEJEWICZ 6.IX.2001). - Jawornik Niebylecki: Łazy, a wooded patch with Betula pendula (OKLEJEWICZ 7.VII.2001). - Brzeżańska Mountain, along a lane in Abies alba forest (OKLEJEWICZ 27.VIII.2001). - Straszydle: Rzeki, scrub along a lane (OKLEJEWICZ 12.X.2000). - Kamienna, Abies alba forest edge (OKLEJEWICZ 12.X.2000). - Białka, along a field track (OKLEJEWICZ 2.VIII.2001). - Wilcze, along a track in an ash-alder wood (OKLEJEWICZ 2.VIII.2001). - Gwoźnica Górna, along a lane, a wooded patch with Betula pendula (OKLEJEWICZ 2.VIII.2001). - Słonik, roadside ditch (OKLEJEWICZ 26.IX.2000). - Tępica, along a field track (OKLEJEWICZ 26.IX.2000). - Pietrusza Wola, along a field track (OKLEJEWICZ 1.VIII.2002). - Rzepnik near Krosno, Pinus sylvestris forest edge (OKLEJEWICZ 30.VI.2000). - Węglówka, by the road (OKLEJEWICZ 6.VIII.2001). - Wólka Bratkowska near Krosno, abandoned farmland (OKLEJEWICZ 17.VII.2001). - Odrzykoń: Podlesie near Krosno, the edge of a Carpinus betulus-Prunus avium thicket (OKLEJEWICZ 17.VII.2001). Podzamcze near Krosno, along a lane (OKLEJEWICZ 6.VIII.2001). - "Prządki" nature reserve near Krosno, forest edge (OKLEJEWICZ 6.VIII.2001). - Czosnki Mountain, along a lane on Carpinus betulus forest edge (OKLEJEWICZ 6.IX.2001). - Czosnki Mountain, S part, along a lane in Carpinus betulus forest (OKLEJEwICZ 6.IX.2001). - Wola Jasienicka: Podlas, scrub along a lane (OKLEJEWICZ 6.IX.2001). - Wola Jasienicka, along a lane (OKLEJEWICZ 6.IX.2001). - Domaradz Galikówka, field margin (OKLEJEWICZ 1.X.2002). - 513.67 Jasło-Krosno Valley: Krosno, Białobrzeska Street, along a lane (OKLEJEWICZ 6.VIII.2001). - 513.68 Jasło Foothills: Duląbka N part, along a field track, and on the edge of a small pinewood (OKLEJEWICZ 27.VII.2002). - Dulabka village, along a field track, and in abandoned meadows (OKLEJEWICZ 27.VII.2002). - Wola Cieklińska, along a lane (OKLEJEWICZ 27.VII.2002). 